\title{
Specific Piliation Directed by a Fertility Factor and a Resistance Factor of Escherichia coli
}

\author{
By Y. NISHIMURA, M. ISHIBASHI, \\ Department of Biology, School of Science, and Genetics Laboratory, \\ School of Medicine, University of Osaka, Osaka, Japan \\ ELINOR MEYNELL, \\ M.R.C. Microbial Genetics Research Unit, Hammersmith Hospital, \\ Ducane Road, London W.12 \\ AND Y. HIROTA \\ Institut Pasteur, 25 rue du Dr Roux, Paris $X V^{e}$ \\ (Accepted for publication 17 April 1967)
}

SUMM ARY

Production of pili directed either by the sex factor $\mathrm{F}$ or by the drugresistance factor R 100 in Escherichia coli $\mathrm{K} I 2$ is regulated by a gene which acts by producing a repressor, and the mutant $\mathrm{R}$ I00-I no longer produces this repressor. The specific pilus determined by $R$ I00-I resembled the $F$ pilus morphologically, but differed in its affinity for F-specific RNA phages. Mutants of F and R IOO-I which had lost the ability to synthesize pili could each restore to the other the ability to produce pili on mixed infection of the same host.

\section{INTRODUCTION}

Filamentous appendages called pili (Brinton, 1965) or fimbriae (Duguid, Anderson \& Campbell, 1966) are produced by most of the enterobacteriaceae under the control of chromosomal genes (Maccacaro, Colombo \& Nardo, I959; Brinton, Gemski, Falkow \& Baron, 196I). However, a special kind of pilus is determined by the sex factor, F, which can be recognized because it specifically adsorbs the spherical particles of certain RNA phages, e.g. RI7 (Crawford \& Gesteland, I964), M I2 (Brinton, Gemski \& Carnahan, I964) and f 2 (Valentine \& Strand, 1965). Brinton (1965) has suggested that the $F$ pilus acts as the conjugation tube through which the chromosome of the male cell is transferred into female $\left(\mathrm{F}^{-}\right)$bacteria and whether or not this is the case, the presence of $F$ pili is certainly essential to conjugation mediated by $F$.

Other extrachromosomal genetic elements such as Resistance Factors ( $R$ factors) responsible for contagious resistance to antibiotics in enteric bacteria (Ochiai, Yamanaka, Kimura \& Sawada, I959; Akiba, Koyama, Isshiki, Kimura \& Fukushima, 1960) confer on $\mathrm{F}^{-}$bacteria the ability to conjugate, as well as to transfer chromosomal genes (Sugino \& Hirota, 1962). To make it possible to observe the formation of specific pili, and thus to clarify the genetic relationship between pili and ability to conjugate, a strain of Escherichia coli $\mathrm{K} I 2$ was used which had none of the ordinary surface appendages like flagella or chromosomally determined pili. Certain $\mathbf{R}$ factors, termed $i^{+}$, co-ordinately inhibit fertility, susceptibility to $\mathrm{F}$ specific phages and 
formation of the specific $\mathrm{f}^{+}$antigen (Hirota, Nishimura, Ørskov \& Ørskov, 1964) in $\mathrm{F}^{+}$bacteria, but mutants, designated $i^{-}$, have been isolated which lack this suppressive effect on F (Egawa \& Hirota, 1962). As shown by Hirota, Fujii \& Nishimura (I966), the $i^{-}$mutant $\mathrm{R} r 00-\mathrm{I}$, of one $\mathrm{R}$ factor, $\mathrm{R} \mathrm{I} 00$, can also restore full $\mathrm{F}$ function to bacteria carrying defective mutants of the $F$ factor such as have been described by Cuzin (1962) and Nishimura (1964). No specific pili were present on $\mathrm{F}^{+}$or $\mathrm{F}^{-}$bacteria

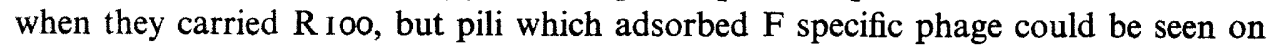
$\mathrm{F}^{+}$bacteria, normal or defective, carrying $\mathrm{R}$ I00-1. The $i^{-}$mutant, $\mathrm{R}$ I00-1, in $\mathrm{F}^{-}$ bacteria brought about conjugation and gave chromosomal recombinants almost as frequently as $F$ itself, suggesting that conjugation is regulated with $R$ roo and that mutation in the $i$ gene of the R factor derepresses its own conjugation function as well as that of $F$. Moreover, specific pili could now be seen on $F^{-}(R$ IOO-I) bacteria. Hirota et al. (1964) were able to show a serological relationship between an antigen determined by $\mathrm{R}$ 100-I and the $\mathrm{F}$ antigen, for an antiserum prepared against $\mathrm{R}$ roo- $\mathrm{I}$ in an $\mathrm{F}^{-}$culture specifically agglutinated $\mathrm{F}^{+}$bacteria. Meynell \& Datta (1966) have reported that in a series of $R$ factors of independent origin, those that inhibited the functions of $F$ themselves determined the production of a pilus sufficiently like the $F$ pilus to adsorb $F$ specific RNA phage. Experiments in Osaka demonstrated the presence of a pilus on $F^{-}\left(R_{100-I}\right)$ bacteria, but no adsorption of phage could be detected. In view of the discrepancy between this result and the conclusion to be drawn from Hirota et al. (I964) and Meynell \& Datta (I966), it was decided to re-examine the pili determined by $\mathrm{R}$ IO0-I for adsorption of $\mathrm{F}$ specific phage.

\section{METHODS}

\section{In Osaka}

Bacteria. Escherichia coli K 12 strain JE2217, used as host for F and R in most of the experiments, had lost type I pilli and flagella by two independent mutations, being a recombinant resulting from a cross between w 2802, a non-flagellate ( $\left.f a^{-}\right)$ mutant of Hfr Cavalli (Cavalli-Sforza, 1950), kindly provided by Dr J. Lederberg, Stanford University, California, and JE 346 which is a pil- mutant of JE 344 unable to produce chromosomally determined pili. Strain JE 344 was an $\mathrm{F}^{-}$derivative obtained by acridine treatment of JE 343 (Hirota, 1960). Inability to swarm on semi-solid agar (Stocker, Zinder \& Lederberg, 1953) was taken to indicate absence of flagella, and failure to haemagglutinate chick red cells absence of type I pili (Duguid, Smith, Dempster \& Edmunds, 1955). The absence of both flagella and type I pili in strain JE22I 7 was also confirmed by electron microscopy. Strain JE2442, a non-lactose fermenting ( $\mathrm{lac}^{-}$) recombinant resulting from a cross between JE $22 \mathrm{I} 7$ and JE I428, Hfr Cavalli lac-52, was used as host for temperature-sensitive F-lacT62.

Salmonella paratyphi $B$ carrying $\mathrm{F}_{\mathrm{I} 3}$ was kindly provided by Dr S. Iseki, Gunma University, Maebashi.

$F$ factors. F 8 and F 13 have been described by Hirota \& Sneath (1961). The temperature-sensitive mutant, F-lacT62 (Jacob, Brenner \& Cuzin, 1963), was kindly provided by Dr F. Cuzin, Institut Pasteur, Paris. Infertile mutants of F 8 were obtained by growing $\mathrm{JE} 2217$ (F8) in broth containing $\mathrm{IO}^{13}$ particles $/ \mathrm{ml}$. of phage $\mathrm{MI} 2$ and selecting phage-resistant bacteria. One such mutant, F8-D I5, def-15, was examined, together with mutants similarly obtained from F-lacT62 D. 
$R$ factors. $\mathrm{R} 100$ is an $\mathrm{R}$ factor conferring resistance to streptomycin $(\mathrm{Sm})$, chloramphenicol $(\mathrm{Cm})$, tetracycline $(\mathrm{Tc})$ and sulphonamide $(\mathrm{Su})$, which appeared in a strain of Shigella flexneri 2 b 222 isolated by Dr R. Nakaya and which has been observed to confer a low degree of fertility on $\mathrm{F}^{-}$bacteria (Sugino \& Hirota, 1962). Its $i^{-}$mutant $\mathrm{R}$ I00- $i^{-}$was obtained by selecting, from cultures of Hfr Cavalli carrying $\mathrm{R}$ Ioo, clones which retained the high fertility of the Hfr (Egawa \& Hirota, 1962; Sugino \& Hirota, 1962). R 100-3I, $i^{-}$, def-3I and $\mathrm{R}$ roo-70, $i^{-}$, def-70 are mutants of $\mathrm{R}$ I00-1 $i^{-}$which have lost their infectivity, and thus their ability to bring about conjugation.

A hybrid factor resulting from recombination between $\mathrm{F}_{\mathrm{I}} 3$ and an incomplete R factor, R23 (Harada, Kameda, Suzuki \& Mitsuhashi, I964), was obtained from Dr K. Harada, Gunma University.

F specific phage. Phage M 12 (Hofschneider, 1963) was kindly provided by Dr P. H. Hofschneider, Max-Planck Institut, München, Germany. Phage sensitivity was tested by the cross-brushing method (Lederberg, 1947), where a loopful of bacterial culture is streaked across a strip of nutrient agar plate previously inoculated with a loopful of phage.

Media. L-broth (Lennox, 1955) and Difco Brain Heart Infusion (BHI) broth were used, and the solid medium was BHI agar.

Electron microscopy. Bacterial cultures in L-broth were diluted ro-fold in fresh medium and grown for $3 \mathrm{hr}$ at $37^{\circ}$ without shaking. To test for adsorption of phage M 12, the phage was added at multiplicities ranging from 10 to 100, together with $5 \cdot 3 \times 10^{-3} \mathrm{M}^{-} \mathrm{CaCl}_{2}$ (Loeb \& Zinder, I96I) and the mixture was incubated for Io min. before transferring a sample to the grid. To examine detached pili, confluent growth on BHI agar was harvested in Davis minimal medium (Davis \& Mingioli, 1950), minus glucose, sedimented by low-speed centrifugation, and the supernatant examined. For shadowcast preparations, duplicate specimens for the electron microscope were prepared by placing drops of suspension on formvar-coated grids, and drawing off the excess. The grids were then rinsed twice with distilled water and allowed to dry in air, and then shadowcast with platinum-palladium alloy. Negative staining (Brenner \& Horne, 1959) was carried out by mixing samples of suspension with phosphotungstate before transferring them to the grids.

\section{In London}

Bacteria. Escherichia coli $\mathrm{K} I 2$ strains JE 254 and JE 255, which carried R 100 and $\mathrm{R}$ 100-I respectively, were provided by $\mathrm{Dr} \mathrm{Y}$. Hirota. These bacteria were $\mathrm{R}^{+}$deri-

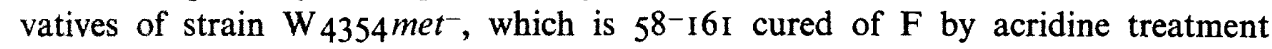
(Hirota, 1960). Other bacterial strains, all lines of E. coli $\mathrm{K} \mathrm{I2}$, were $\mathrm{J}^{-3}$ pro $^{-} \mathrm{met}^{-}$, an acridine-cured derivative of an $\mathrm{F}^{+}$strain, and $\mathrm{RC} 12 \mathrm{thr}^{-}$leu-thi, which came from the $\mathrm{F}^{-}$strain W II77. These strains are fully described in Meynell \& Datta (1966). Strains $58-16 \mathrm{I} \mathrm{F}^{+}$and $\mathrm{HfrH}$ were used as indicators for the phages.

F specific phages. Three RNA phages, MS 2 (Davis, Strauss \& Sinsheimer, 196r), $\mu 2$ (Dettori, Maccacaro \& Piccinin, 196I) and f 2 (Loeb \& Zinder, I96I), were tested.

Sensitivity of a bacterial strain to lysis was tested both by spotting a drop of hightitre phage preparation on the surface of a nutrient agar plate spread with a loopful of broth culture, and by assaying dilutions of the phage preparation for plaques in a soft agar overlay. The presence of any phage-sensitive bacteria in cultures was detected by incubating mixtures of bacteria with excess phage, and plating for infective centres 
(phage-infected bacteria) on the sensitive indicator strain, $\mathrm{HfrH}$, after passing the mixture through antiphage serum to inactivate residual free phage. The media and experimental techniques are given fully in Datta, Lawn \& Meynell (1966).

\section{RESULTS}

In Osaka

Strains JE 22I 7 and JE2443, which produced neither flagella nor type I pili, were examined in the electron microscope after infection with the different $\mathrm{F}$ and $\mathrm{R}$ factors.

The results are shown in Table I and Plates I and 2, and can be summarized as follows.

Specific piliation directed by the $F$ factor. $\mathrm{F}^{-} \mathrm{R}-$ bacteria showed no pili(Table $\mathrm{I}$, lines $\mathrm{I}$ and 2 ; PI. I, fig. I). Infection with F 8 led to the formation of a few pili per bacterium, to which the F specific phage M I 2 could attach (Table I, lines 3 and 4 ; Pl. I, figs 2, 3 and Pl. 2, fig. 4). These pili were generally longer than type I pili, and some measured $20 \mu$ or more. Addition of anti- $\mathrm{f}^{+}$serum to the cultures causes agglutination of the pili; this is a specific effect of the antibody and does not occur with normal serum, showing that the $\mathrm{F}$ pilus constitutes at least part of the specific $\mathrm{f}^{+}$antigen (Ishibashi, 1967).

Salmonella paratyphi $B$ carrying F 13 could be seen to produce similar pili.

Detached pili in the supernatant of centrifuged broth cultures showed an outer diameter of about $100 \AA$ and were often aggregated. They were still capable of adsorbing particles of phage $\mathrm{MI}_{\mathrm{I}}$, and the protein coats of the attached phage particles were empty, in contrast to what has been reported for phage f 2 (Valentine \& Strand, 1965).

Inhibition of $F$ piliation by $R$ factors. The wild type $i^{+} \mathrm{R}$ factor, $\mathrm{R} 100$, co-ordinately inhibits the functions of $F$, so that an $F^{+}\left(R_{100}\right)$ culture loses its sensitivity to lysis by $F$ specific phage and agglutinability by $F$ specific antiserum, and conjugates at much reduced frequency (Hirota et al. 1964). Such $\mathrm{F}^{+}(\mathrm{R}$ I00) bacteria could not be seen to produce any $F$ pili (Table $I$, line 8 ). When, however, instead of $\mathrm{R} I 00$, its $i^{-}$mutant, $\mathrm{R}$ I00-I, was used, which does not suppress the function of F, F pili were formed to which phage M I 2 could readily be seen to adsorb (Table I, line 9). Thus, all the several effects of the $i^{+}$character of $\mathrm{R} 100$ appear to result from inhibition of formation of the F pilus.

Piliation directed by $R$ factors. No pili could be detected on bacteria infected with the wild-type R factor, R IOo (Table I, line 5), and no detached pili could be found in the supernatant of centrifuged broth cultures. The $i^{-}$mutant, R roo-I, brings about conjugation and transfer of drug resistance at much higher frequency than $\mathrm{R} 100$ (Table I, line 6) and with R I00-I, bacteria bearing pili could readily be seen (PI. 2, fig. 5). The pili on $\mathrm{F}^{-}\left(\mathrm{R}_{100-1}\right)$ bacteria were morphologically distinguishable from both flagella and type I pili, and disappeared when the $R$ factor was eliminated by acridine treatment. They evidently differed from $F$ pili, however, for there was no adsorption of phage $M_{12}$. The frequency of piliation in $F^{-}\left(R_{100-I)}\right.$ cultures was about one tenth of that in $\mathrm{F}^{+}$cultures, and a larger proportion of the pili produced were very short $(0 \cdot \mathrm{I}-\mathrm{I} \cdot 0 \mu)$.

Piliation directed by $a$ hybrid of $F$ and an $R$ factor. When $\mathrm{R}$ factors are transduced by salmonella phages, they are generally transferred only in part, and the transductants 


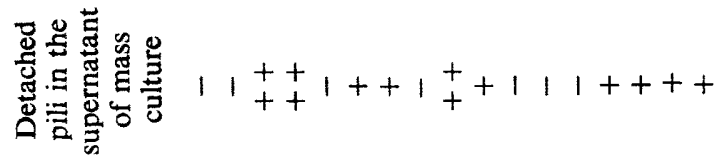

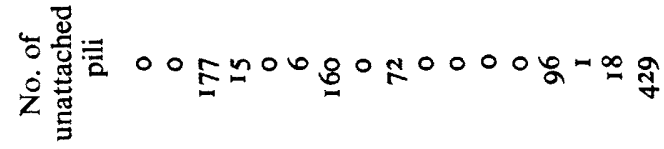

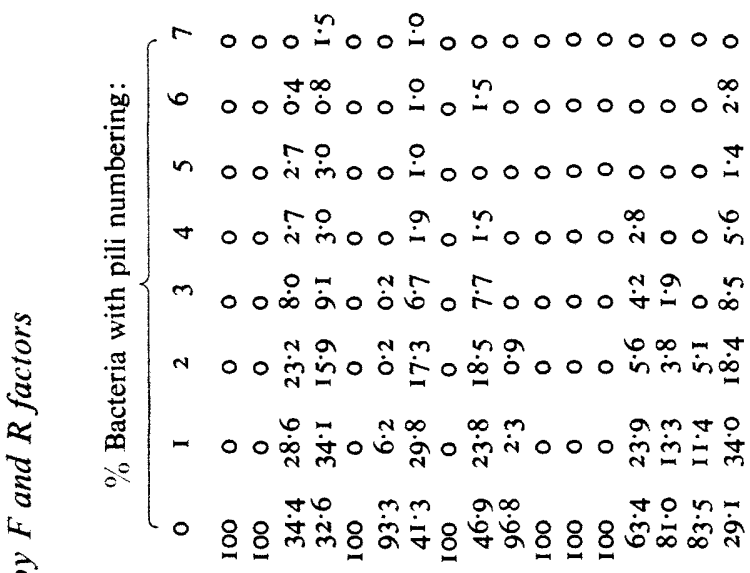

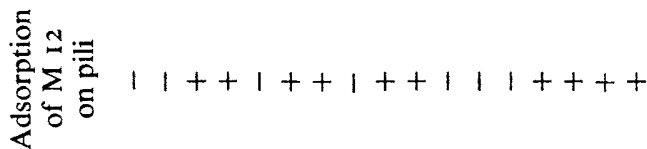

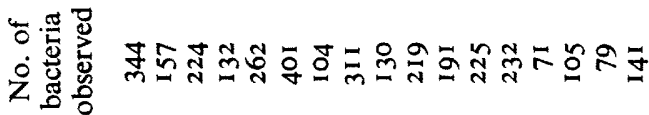

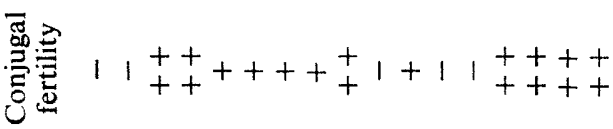

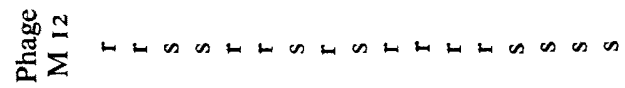

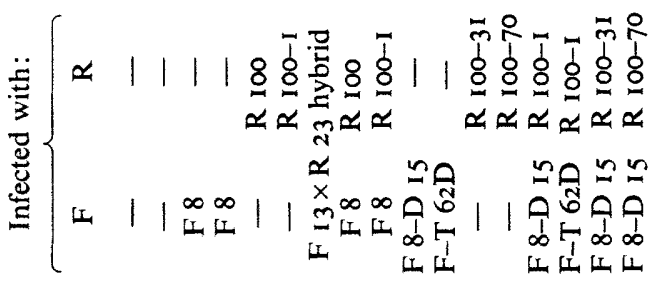

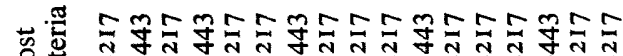

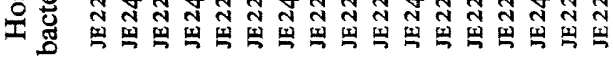
章 - 
fail to receive some of the drug resistances as well as the ability to pass on the $\mathrm{R}$ factor by conjugation (Watanabe \& Fukasawa, 196I). Such an incomplete R factor, R 23, is part of a complete $\mathrm{R}$ factor, $\mathrm{R} \mathrm{ro}(\mathrm{Tc} \mathrm{Cm} \mathrm{Sm} \mathrm{Su})$, conferring only its tetracycline resistance. A hybrid factor resulting from recombination between $\mathrm{F}_{13}$ and $\mathrm{R} 23$ was obtained by Harada et al. (1964), and shown to give sensitivity to F specific phage. Strain JE 2443 carrying this hybrid factor produced pili to which phage M I 2 could be seen to adsorb with the same efficiency as to F pili (Table I, line 7).

Defective mutants of Fand $R$ factors. The reduced fertility mutant F8-D 15 was found to give only an occasional piliated bacterium, to which phage M I2 adsorbed (Table I, line 10). Defective mutants similarly derived from the temperature-sensitive F-lacT62 factor gave, at $30^{\circ}$, under optimal conditions for reproduction of the F-lacT62 factor very low frequencies of F-lac transfer $\left(c . \mathrm{IO}^{-5}\right.$ per donor) and no chromosomal recombinants nor piliated bacteria could be found (Table I, line I I). Nor could piliated bacteria be seen with R I00-3I or R I00-70, mutants of R I00-I which showed reduced frequency of drug-resistance transfer, and were taken to be less effective in promoting conjugation (Table I, lines 12 and 13 ). Thus, mutants of $F$ or $R$ factors defective in conjugal activity are also defective in piliation.

Restoration of defective $F$ piliation by R roo-I. When bacteria carrying the defective F factor, F8-D I5, were also infected with R I00-I, this restored their ability to transfer the gal gene of F8 and to give chromosomal recombinants; in addition, the numbers of piliated bacteria increased to nearly the level found with F8 itself (Table I, line 14). The pili present on F8-D I5 (R IOO-I) bacteria resembled typical F pili in readily adsorbing phage MI2. Similar results were obtained with $\mathrm{R}_{100-\mathrm{I}}$ and the defective mutants of F-lacT62 (Table I, line I5).

Complementation evidently occurred between defective $\mathrm{F}$ factors and defective $\mathrm{R}$ factors for bacteria carrying both F8-Di5 and one or other of R I00-3I and $\mathrm{R}$ I00-70, produced pili like typical F pili (Table I, lines 16 and 17 ). This is in accord with the previous observation that Hfr strains that had lost fertility and phage sensitivity through a mutation in the F factor (Lederberg \& Lederberg, 1956) regained both properties when they were infected with R I00-I itself or with one of its defective mutants (Nishimura, I964; Hirota et al. 1966).

\section{In London}

Presence of $F$ phage sensitive bacteria in cultures of bacteria carrying $R I 00$ and $R$ IOO-I. When phage MS 2 was added at $5 \times 10^{9}$ particles $/ \mathrm{ml}$. to cultures of JE 254 ( $\mathrm{R} 100$ ) which had been freshly grown to a bacterial concentration of $2 \times 10^{8} / \mathrm{ml}$., and $8 \mathrm{~min}$. were allowed for adsorption before free phage was neutralized by addition of antiserum, the numbers of plaques produced on the indicator strain, $\mathrm{HfrH}$, suggested that about $\mathrm{I}$ in 1000 of the bacteria had been infected. The conclusion that phagesensitive bacteria were present in this strain was supported by finding that further incubation of the cultures for about $2 \mathrm{hr}$ led to a considerable increase of phage.

When JE 255 (R IO0-I) was tested in the same way for phage-sensitive bacteria, a much larger number of infective centres was obtained, corresponding to $2-10 \%$ of the bacteria in different experiments, and the increase of phage after incubation of the cultures was proportionately greater. It was not possible to estimate the precise proportions of bacteria which could be infected, for cultures of JE 255 in liquid medium undergo spontaneous aggregation into clumps (Hirota et al. 1964); thus an individual 
plaque could just as well arise from a clump of several infected bacteria as from a single one. Broth cultures inoculated from morphologically smooth colonies agglutinated as markedly as cultures of bacteria producing rough colonies. The aggregation in broth was evidently directly due to the pilus, for pili are poorly formed on solid medium, and broth cultures of JE254 (R IOO), which contained very few piliated bacteria, were evenly dispersed.

From these results, it appeared that the pilus determined by the $\mathrm{R}$ factor, $\mathrm{R}$ Ioo, did have some affinity for phage MS2. Electron-microscopic examination of mixtures of JE255 bacteria and phage MS 2, kindly performed by Dr A. M. Lawn, Lister Institute of Preventive Medicine, showed in addition to type I pili, spherical particles of the phage attached to the specific pili. Seventy per cent of the bacteria bore pili with particles of phage MS 2 attached, but fewer phage particles were attached to each of these pili than in the usual preparations of $\mathrm{F}^{+}$bacteria (A. M. Lawn, personal communication).

Table 2. Relative efficiencies of plating of male-specific $R N A$ phages $M S 2, \mu 2$ and $f 2$ on JE $255(R 100-I)$

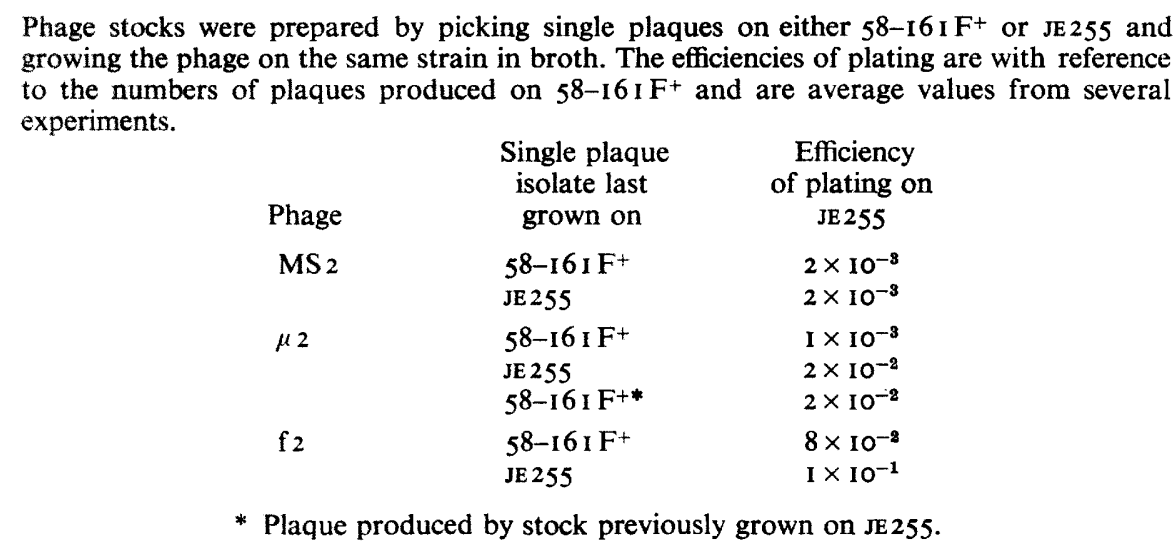

The numbers of phage MS 2 infective centres obtained with strain JE255 (R IO0-I) suggested that the proportion of infectable bacteria might be high enough to allow the phage to lyse cultures macroscopically on solid medium, and, on testing, drops of undiluted phage stock produced patches of clearing, and dilutions gave plaques. Strain JE 255 was less sensitive, however, than $\mathrm{F}^{+}$indicator strains like $58-16 \mathrm{I} \mathrm{F}^{+}$or $\mathrm{HfrH}$, for the clearing with undiluted phage was less complete and individual plaques were more turbid and heterogeneous in size. The efficiency of plating was considerably lower than on $\mathrm{F}^{+}$bacteria and most of the plaques were extremely small. Table 2 shows the results of testing the three F specific RNA phages, MS 2, $\mu 2$ and $\mathrm{f} 2$, in parallel on $58-16 \mathrm{I} \mathrm{F}^{+}$and JE255. It can be seen that the efficiency of plating on JE255 differed for each phage; the values remained approximately the same in repeated titrations and reproducible titres were obtained with the phage stocks, thus excluding the possibility that the differences between the phages were due to chance fluctuations resulting from occasional failure to observe and count the smallest plaques.

Heterogeneity in plaque size, such as was observed here, is often indicative of inefficient adsorption. The rates of adsorption to JE 255 and $58-16 \mathrm{IF}^{+}$were directly 
compared using preparations of the three phages made on JE 255. Phage was mixed for $10 \mathrm{~min}$. at $37^{\circ}$ with bacteria freshly grown to a concentration of $5 \times 10^{8} / \mathrm{ml}$. in broth, and the supernatant was assayed after centrifugation. With strain $58-16 \mathrm{IF}^{+}, 77 \%$ of phage MS 2 (added at $1.5 \times 10^{7} / \mathrm{ml}$ ), $76 \%$ of phage $\mu 2$ (added at $4 \times 10^{7} / \mathrm{ml}$.) and $90 \%$ of phage f 2 (added at $2.6 \times 10^{7} / \mathrm{ml}$ ) were absorbed; with JE 255 , adsorption was too poor for a decrease in free phage to be detected with any of the three phages.

Strain JE 255 is a derivative of 58-16I cured of its F factor by acridine treatment. In case the particular kind of pilus, able to adsorb phages $\mathrm{MS} 2, \mu 2$ and $\mathrm{f} 2$, determined in this strain was due to some peculiarity of the strain itself, R I00-I was tested in two other lines of $E$. coli $\mathrm{KI}$, strain RCI2 and strain J 5-3, and these were both lysed macroscopically by phage MS 2 .

\section{DISCUSSION}

The $i^{+} \mathrm{R}$ factor, $\mathrm{R}$ Ioo, which suppresses conjugation in $\mathrm{F}^{+}$bacteria by producing a repressor of $F$ function (Egawa \& Hirota, 1962) prevents the formation of $F$ pili on $\mathrm{F}^{+}(\mathrm{R} 100)$ bacteria. However, with the $i^{-}$mutant, $\mathrm{R} 100-\mathrm{I}, \mathrm{F}^{+}$bacteria continue to conjugate normally and can be seen to produce pili apparently identical with those of $F^{+} R^{-}$bacteria. Using bacterial strains without other surface appendages such as flagella or type I pili, it has been possible to observe that $F^{-}\left(R_{100-I}\right)$ bacteria produce pili which are morphologically like $F$ pili but which can be distinguished from them by a lesser affinity for F specific RNA phages. With strains JE 2217 and JE2443 used in Osaka, no adsorption of phage MI2 to these pili could be detected. With strains JE 255, RCI 2 and J 5-3, examined in London, some attachment of phages MS $2, \mu 2$ and $\mathrm{f} 2$ could be demonstrated, but it was markedly less than with an $\mathrm{F}$ pilus.

The $i^{+}$to $i^{-}$mutation leading from $\mathrm{R} 100$ to $\mathrm{R}$ I00-I is associated both with a loss of inhibition of $F$ function and with the appearance of piliated bacteria in $F^{-}(R)$ cultures. Since pili are produced by $\mathrm{F}^{-}$bacteria when they carry $\mathrm{R}$ I00-I but not when they carry R I00, it may be concluded that the cytoplasmic repressor produced by the $i$ gene of R 100 (Egawa \& Hirota, 1962; Hirota et al. 1964) suppresses its own piliation as well as that of $F$. These regulatory changes may be compared with the operon model for enzyme synthesis in $E$. coli (Jacob \& Monod, I96I), R I00-I being a constitutive mutant $\mathrm{R}$ factor unable to synthesize the cytoplasmic repressor of $\mathrm{R}$ and $\mathrm{F}$ mediated piliation. Meynell \& Datta (I966) reported that those R factors which determine the production of a pilus resembling the $F$ pilus are the same as those whose own repressor of function also repressed the function of F. Minor differences between the pili determined by these $R$ factors and by $F$ would not have been detected in their experiments, but in the present case it has been possible to discern a difference in structure between $\mathrm{R}$ I00-I pili and $\mathrm{F}$ pili as reflected in their different affinities for $\mathrm{F}$ specific phages. At the same time, using both $\mathrm{F}^{+}$and ( $\left.\mathrm{R} \mathrm{IOO}-\mathrm{I}\right)^{+}$bacteria as indicator strains, it was possible to detect differences between each of the three F specific phages, MS 2, $\mu 2$ and $\mathrm{f} 2$.

The interactions between $F$ and R 100 in pilus production are set out in Table 3. Wild-type F produces pili constitutively, while $\mathrm{R} \mathrm{I00-I}$ is a constitutive mutant of $\mathrm{R}$ I00 failing to synthesize repressor. $\mathrm{F}^{+}\left(\mathrm{R}_{\mathrm{I00}-\mathrm{I})}\right.$ bacteria produce $\mathrm{F}$ pili, while $\mathrm{F}^{-}$( $\mathrm{R}$ I00-I) bacteria produce $\mathrm{R}$ I00 pili, which, although serologically related (Hirota et al. 1964), differ somewhat in structure from $\mathrm{F}$ pili. The structural genes determining pilus production in $\mathrm{F}$ and in $\mathrm{R} 100$ may be thought of as allelic, for they are subject to 
the same control of function and their products, although not identical, are alike in kind. Defective mutants of $\mathrm{F}$ and of $\mathrm{R}$ IOO-I unable to determine the production of pili have evidently mutated in genes controlling an organelle producing pili specific for F or R 100; pilus production is restored to the cell when a normal F or R roo-I factor is introduced, showing that the absence of pili is due to a mutation which is recessive to the wild type, as opposed to production of repressor.

\section{Table 3. Control of pili formation by $F$ and $R$ factors}

\begin{tabular}{|c|c|c|c|}
\hline $\begin{array}{l}\text { Genotypes } \\
\text { of } F \text { and } R\end{array}$ & $\begin{array}{l}\text { Pili in } \\
\text { established } \\
\text { cultures }\end{array}$ & $\begin{array}{c}\text { Pili on } \\
\text { newly } \\
\text { infected } \\
\text { bacteria }\end{array}$ & $\begin{array}{c}\text { Type } \\
\text { of pilus }\end{array}$ \\
\hline $\mathrm{F}\left(i^{-}\right)$ & Present & . & F \\
\hline $\mathrm{R} i^{+} / \mathrm{F}\left(i^{-}\right)$ & Absent & . & \\
\hline $\mathrm{R} i^{-} \mathrm{F}\left(i^{-}\right)$ & Present & & $\mathbf{F}$ \\
\hline $\mathbf{R} i^{+}$ & Absent & Present* & $\mathbf{R}$ \\
\hline $\mathrm{R} i^{-}$ & Present & & $\mathbf{R}$ \\
\hline $\mathrm{R} i^{+} / \mathrm{R} i^{-}$ & Absent & & \\
\hline $\mathrm{R} i^{-} / \mathbf{F}\left(i^{-}\right) d e f$ & Present & & $\mathrm{F}$ \\
\hline $\mathrm{R} i^{-} \operatorname{def} / \mathrm{F}\left(i^{-}\right) \operatorname{def}$ & Present & . & $\mathrm{F}$ \\
\hline
\end{tabular}

* Datta, Lawn \& Meynell (1966).

It is also clear that genetic alterations resulting in loss or acquisition of $\mathrm{F}$ or $\mathrm{R}$ pili are strictly correlated with loss or gain of ability to transfer the chromosome by conjugation. Thus, the presence of pili, determined by $F$ or by $R$ factors, is essential for conjugation, whether or not the pilus itself acts as the tube through which the donor chromosome is transferred to the recipient bacterium as postulated by Brinton (1965).

\section{REFERENCES}

Akiba, T., Koyama, T., Isshiki, T., Kimura, S. \& Fukushima, T.(1960). Studies on the mechanism of development of multiple drug resistant Shigella strains. Jap. J. med. Sci. Biol. no. I866, p. 46.

BrenNer, S. \& Horne, R. W. (1959). A negative staining method for high resolution electron microscopy of viruses. Biochim. biophys. Acta 34, 103.

BRINTON, C. C. (1965). The structure, function, synthesis and genetic control of bacterial pili and a molecular model for DNA and RNA transport in gram-negative bacteria. Trans. N.Y. Acad. Sci. 27, 1003.

Brinton, C. C., Gemski, P. \& Carnahan, J. (1964). A new type of bacterial pilus genetically controlled by the fertility factor of $E$ coli K-1 2 and its role in chromosome transfer. Proc. natn. Acad. Sci. U.S.A. 52, 776.

Brinton, C. C., Gemski, P., Falkow, S. \& Baron, L. S. (I96I). Location of the piliation factor on the chromosome of Escherichia coli. Biochem. biophys Res. Commun. 5, 293.

Cavalli-Sforza, L. L. (1950). La sessualita nei batteri. Boll. Ist. sieroter. milan. 29, 28 I.

CRAwford, E. M. \& Gesteland, R. F. (1964). The adsorption of bacteriophage R-I 7. Virology 22, 165.

Cuzrn, F. (1962). Mutants défectifs de l'episome sexuel chez Escherichia coli K-12. C. r. hebd. Séanc. Acad. Sci., Paris 255, 1 I 49.

Datta, N., Lawn, A. M. \& Meynell, E. (1966). The relationship of F type piliation and F phage sensitivity to drug resistance transfer in $\mathrm{R}^{+} \mathrm{F}^{-}$Escherichia coli $\mathrm{K}$ I2. J. gen. Microbiol. 45,365 .

Davis, J. B. \& Mingioli, E. S. (1950). Mutants of E. coli requiring methionine or vitamin B I2. J. Bact. 60, 17.

Davis, J. E., Strauss, J. H., JR. \& Sinsheimer, R. L. (I96I). Bacteriophage MS 2: another RNA phage. Science, N.Y. 134, 1427.

Detrori, R., Maccacaro, G. A. \& Piccinin, G. L. (I96I). Sex-specific bacteriophages of Escherichia coli K I2. G. Microbiol. $9,141$.

Duguid, J. P., Anderson, E. S. \& Campbell, I. (I966). Fimbriae and adhesive properties in Salmonellae. J. Path. Bact. 92, 107. 
Duguid, J. P., Smith, I. W., Dempster, G. \& Edmunds, P. N. (I955). Non-flagellar filamentous appendages ('fimbriae') and haemagglutinating activity in Bacterium coli. J. Path. Bact. 70, 335.

EgawA, R. \& Hirota, Y. (1962). Inhibition of fertility by the resistance factor (R) in Escherichia coli K-12. Jap. J. Genet. 37, 66.

Harada, K., Kameda, M., Suzuki, M. \& Mitsuhashi, S. (1964). Drug resistance of enteric bacteria. III. Acquisition of transferability of nontransmissible R (TC) factor in cooperation with F factor and formation of FR (TC). J. Bact. 88, 1257.

Hirota, Y. (1960). The effect of acridine dyes on mating type in Escherichia coli. Proc. natn. Acad. Sci. U.S.A. 46, 57.

Hirota, Y. \& SNEATH, P. H. A. (1961). $F^{\prime}$ and F-mediated transduction in Escherichia coli K-I2. Jap. J. Genet. 36, 307.

Hirota, Y., Fuin, T. \& Nishimura, Y. (1966). Loss and repair of conjugal fertility and infectivity of the resistance factor and sex factor in Escherichia coli. J. Bact. 9x, 1298.

Hirota, Y., NishimuRA, Y., ØRSKov, F. \& ØRSKOV, I. (1964). Effect of drug-resistance factor R on the F properties of Escherichia coli. J. Bact. 87, 341 .

HoFsCHNEDER, P. H. (1963). Untersuchungen über 'Kleine' E, coli K-I 2 Bakteriophagen. Z. Naturf. $18 b, 203$.

ISHIBASHI, M. (I967). F pilus as $f^{+}$antigen. J. Bact. 93, 379.

JACOB, F. \& MONOD, J. (1961). Genetic regulatory mechanisms in synthesis of proteins. J. molec. Biol. 3, 318.

JACOB, F., BRENNER, S. \& CUZIN, F. (1963). On the regulation of DNA replication in bacteria. Cold Spring Harb. Symp. quant. Biol. 28, 329.

LEDERBERG, J. (1947). Gene recombination and linked segregation in Escherichia coli. Genetics 32, 505.

LederberG, J. \& Lederberg, E. M. (1956). Infection and heredity. In Cellular Mechanisms in Differentiation and Growth (ed. by D. Rudnick), p. IoI. Princeton, N.J.: Princeton University Press.

LENNOX, E. S. (1955). Transduction of linked genetic characters of the host by bacteriophage P I. Virology $\mathrm{x}, 190$.

LoEB, T. \& ZINDBR, N. D. (1961). A bacteriophage containing RNA. Proc. natn. Acad. Sci. U.S.A. 47, 282.

Maccacaro, G. A., Colombo, C. \& Nardo, A. di (1959). Studi sulle fimbrie batteriche. I. Lo studio genetico delle fimbrie. G. Microbiol. 7, I.

Meynell, E. \& DatTA, N. (1966). The relation of resistance transfer factors to the F factor (sex factor) of Escherichia coli K-1 2. Genet. Res. 7, 134.

Nishimura, Y. ( I964). Defective mutations of sex compatibility in Escherichia coli. Jap. J. Genet. 39, 360.

Ochiai, K. T., Yamanaka, T., Kimura, K. \& Sawada, O. (1959). Studies on transfer of drug resistance between Shigella strains and Escherichia coli strains. Jap. J. med. Sci. Biol. no. 186r, p. 34 .

StOCKER, B. A. D., ZINDER, N. D. \& LeDerberg, J. (1953). Transduction of flagellar characters in Salmonella. J. gen. Microbiol. 9, 410.

Sugino, Y. \& HiRota, Y. (1962). Conjugal fertility associated with resistance factor R in Escherichia coli. J. Bact. 84, 902.

Valentine, R. C. \& Strand, M. (1965). Complexes of F-pili and RNA bacteriophage. Science, N.Y. I48, 5 II.

Watanabe, T. \& Fukasawa, T. (1961). Episome mediated transfer of drug resistance in Enterobacteriaceae. III. Transduction of resistance factors. J. Bact. 82, 202.

\section{EXPLANATION OF PLATES}

\section{Plate I}

Electron micrographs by platinum-palladium shadow-casting technique $(\times 20,000)$.

Fig. I. JE 2217 (F-pil-fla $)$.

Fig. 2. JE2217 carrying F8.

Fig. 3. Phage M 12 adsorbed to JE 2217 (F8).

Plate 2

Fig. 4. Electron micrograph of detached $F$ pili with absorbed phage $M_{12}$ : phosphotungstate negative staining technique $(\times 100,000)$.

Fig. 5. Electron micrograph of JB 2217 carrying R 100-I : platinum-palladium shadow-casting technique $(\times 20,000)$. 

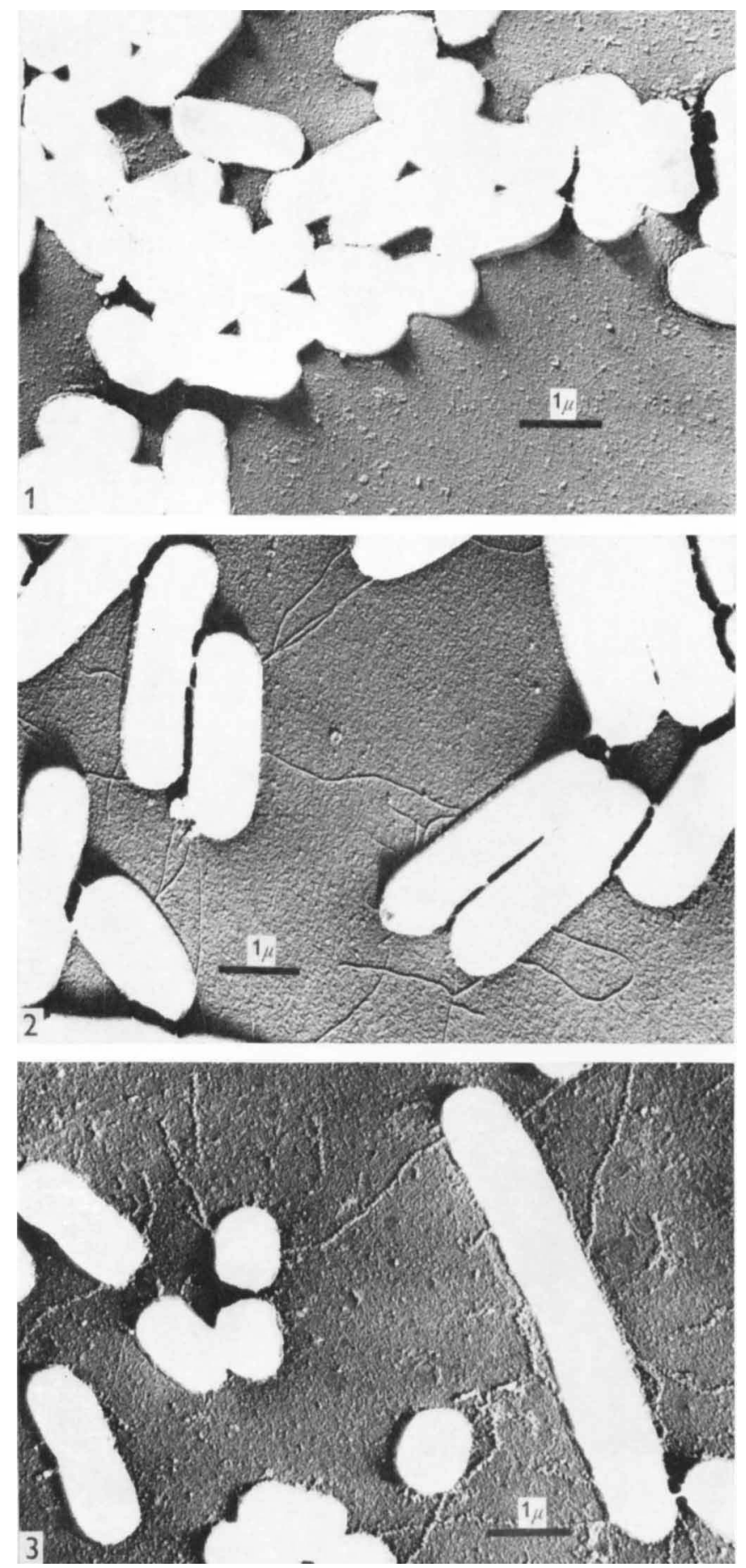
Journal of General Microbiology, Vol. 49, No. 1

Plate 2
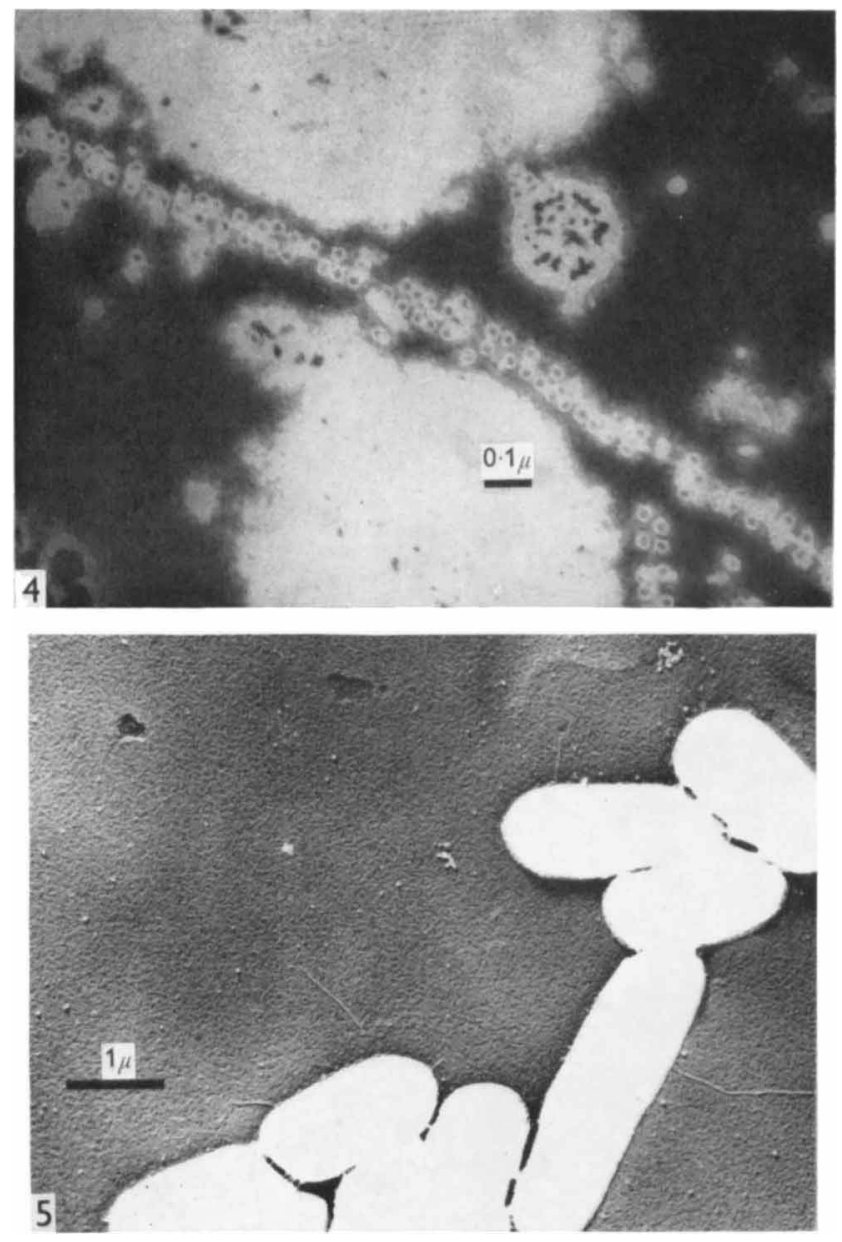